\title{
KARAKTERISTIK METASTASIS SISTEM SARAF PUSAT DARI KANKER PARU
}

\author{
CENTRAL NERVOUS SYSTEM METASTASIS OF LUNG CANCER CHARACTERISTIC
}

\author{
Tan Yosephine, * Tiara Aninditha, ** Henry Riyanto Sofyan, ** Jonathan Odilo, *** Rini Andriani****
}

\section{ABSTRACT}

Introduction: As much as 40\% of lung cancer patients will experience central nervous system (CNS) metastasis in the course of the disease. From those 40\%, as much as 3-9\% will experience leptomeningeal metastasis, but the clinical profile of CNS involvement in lung cancer has never been studied before in Indonesia.

Aim: To give a description of CNS metastasis from lung cancer in Cipto Mangunkusumo General Hospital and National Cancer Referral Dharmais Hospital.

Methods: This is a cross-sectional study done in patients consulted to Neurology Department in Cipto Mangunkusumo General Hospital and National Cancer Referral Dharmais Hospital in 2018. Inclusion cirteria is adult patients diagnosed with lung cancer based on histopathology with complete medical record to the extent of CT scan or Head MRI with contrast.

Results: There were 48 subjects with median age of 57 (36-76) years, men were more than women (56.2\% vs 44.8\%) and $31.3 \%$ had history of smoking. The most frequent lung cancer type is non-small cell lung cancer (NSCLC) (93,8\%). Neurological symptoms found were motoric deficits (62.5\%), headache (43.8\%), cognitive dysfunction (20.8\%), and seizure (18.8\%). Majority of subjects suffered from brain metastasis (93.8\%) and 8.3\% were leptomeningeal metastasis.

Discussion: The majority of CNS metastasis were brain metastasis from NSCLC (93.8\%) with main neurological deficits were motoric deficits (62.5\%) and headache (43.8\%).

Keywords: Brain metastasis, lung cancer, non-small cell lung carcinoma

\section{ABSTRAK}

Pendahuluan: Sebanyak 40\% pasien dengan kanker paru akan mengalami metastasis sistem saraf pusat (SSP) dalam perjalanan penyakitnya. Dari 40\% tersebut, sebanyak 3-9\% akan mengalami metastasis leptomeningeal, namun profil klinis keterlibatan SSP pada kanker paru belum pernah diteliti di Indonesia.

Tujuan: Mengetahui gambaran metastasis SSP kanker paru di RSUPN Dr. Cipto Mangunkusumo (RSCM) dan RS Kanker Dharmais (RSKD).

Metode: Penelitian potong lintang terhadap pasien kanker paru yang dikonsulkan ke bagian Neurologi di RSCM dan RSKD sepanjang tahun 2018. Kriteria inklusi adalah pasien dewasa yang sudah terdiagnosis sebagai kanker paru berdasarkan pemeriksaan histopatologi dan memiliki data rekam medis lengkap, hingga gambaran CT scan atau MRI kepala dengan kontras.

Hasil: Didapatkan 48 subjek dengan median 57 (36-76) tahun, proporsi laki-laki lebih banyak dari pada perempuan (56,2\% vs 44,8\%) dan 31,3\% mempunyai riwayat merokok. Jenis tumor paru tersering adalah kanker paru karsinoma bukan sel kecil (KPKBSK) atau non-small cell lung carcinoma (SCLC) (93,8\%). Gejala neurologis terutama defisit motorik (62,5\%), nyeri kepala (43,8\%), gangguan fungsi luhur (20,8\%), dan kejang (18,8\%). Mayoritas subjek mengalami metastasis di otak $(93,8 \%)$ dan sebanyak $8,3 \%$ di leptomeningeal.

Diskusi: Didapatkan tumor otak akibat metastasis dari kanker paru dengan jenis KPKBSK (93,8\%) dengan gejala neurologis utama defisit motorik $(62,5 \%)$ dan nyeri kepala $(43,8 \%)$.

Kata kunci: Kanker paru, karsinoma sel kecil, metastasis otak.

\begin{abstract}
*Staf SMF Neurologi RSUP Persahabatan, Jakarta; **Departemen Neurologi FK Universitas Indonesia/RSUPN Dr. Cipto Mangunkusumo, Jakarta;***FK Universitas Indonesia, Jakarta; ****SMF Neurologi Pusat Kanker Nasional RS Dharmais, Jakarta. Korespondensi:tanyosephinesps@gmail.com.
\end{abstract}

\section{PENDAHULUAN}

Metastasis otak merupakan salah satu komplikasi neurologis pada keganasan sistemik. Insidensnya meningkat seiring dengan canggihnya deteksi keganasan dan berkembangnya tatalaksana penanganan kanker, hingga melebihi insidens tumor otak primer. ${ }^{1-3}$ Secara umum, semua tumor yang bersifat ganas dapat bermetastasis ke otak. Pada pasien dewasa, tumor primer yang paling sering bermetastasis ke otak adalah paru (36-64\%), payudara (15-20\%), dan melanoma (5-20\%). ${ }^{1,4}$ Menurut WHO 2018, dijumpai kasus baru kanker paru sebesar 8,6\% 
setiap tahun dan angka kematian akibat kanker paru sebesar $12,6 \%{ }^{5}$

Kanker paru adalah tumor ganas yang berasal dari epitel bronkus atau karsinoma bronkus (bronchogenic carcinoma). Karakteristik klinis penderitanya lebih banyak pada laki-laki berusia 40-70 tahun dengan faktor risiko utama merokok. Faktor risiko kanker paru lainnya adalah pajanan radiasi, paparan okupasi terhadap bahan kimia karsinogenik, riwayat kanker pada pasien atau keluarga pasien, dan riwayat penyakit paru seperti penyakit paru obstruktif kronik (PPOK) atau fibrosis paru. ${ }^{6}$ Secara epidemiologi, kanker paru merupakan kanker dengan insidens dan kematian paling banyak di dunia. Insidens dan angka mortalitasnya mencapai 22,5 dan 18,6 per 100.000 orang di dunia. ${ }^{7}$ Sementara di Indonesia, kanker paru menempati urutan pertama insidens pada laki-laki dan ketiga untuk gabungan laki-laki dan perempuan. ${ }^{5}$

Metastasis sistem saraf pusat (SSP) pada kanker paru pernah dideskripsikan sebelumnya. Metastasis tersebut dapat terjadi di otak, leptomeningeal, dan spinal intrameduler/ekstrameduler. Kanker paru merupakan kanker dengan penyumbang metastasis otak paling banyak dengan $40-50 \%$ total metastasis otak berasal dari kanker paru. Secara patologi, kanker paru dibagi dalam 2 subtipe besar, yaitu kanker paru karsinoma sel kecil (KPKSK) atau small cell lung carcinoma (SCLC) dan kanker paru karsinoma bukan sel kecil (KPKBSK) atau non-small cell lung cancer (NSCLC) dengan proporsi $15 \%$ dan $85 \%$ dari total kasus. ${ }^{8}$ Pada pasien dengan tipe histopatologi KPKSK, insidens metastasis otak selama perjalanan penyakit mencapai $20-40 \%$. Sementara itu, pada pasien dengan KPKBSK, setengah populasi terdiagnosis dengan metastasis otak saat diagnosis awal, dan setengah populasi akan menderita metastasis otak pada tahap selanjutnya. Metastasis leptomeningeal pada kanker paru terjadi pada 10\% pasien kanker paru. Metastasis leptomeningeal biasanya dijumpai pada pasien dengan penyakit sistemik tahap lanjut dan tidak terkontrol. Sementara itu, metastasis spinal ekstrameduler dari kanker paru berkisar 3-6\%. Metastasis spinal intrameduler jarang ditemukan pada kanker paru. ${ }^{9}$
Hingga saat ini, sudah diketahui karakteristik dan epidemiologi metastasis SSP pada kanker paru. Namun, belum diketahui karakteristik klinis dan demografis serta perbedaan gejala neurologis subjek metastasis SSP pada KPKBSK dan KPKSK. Penelitian mengenai keterlibatan SSP pada kanker paru belum pernah dilakukan di Indonesia. Penelitian ini penting dilakukan untuk mengetahui karakteristik metastasis SSP pada pasien-pasien di Indonesia.

\section{TUJUAN}

Mengetahui gambaran metastasis SSP kanker paru di RSUPN Dr. Cipto Mangunkusumo (RSCM) dan RS Kanker Dharmais (RSKD).

\section{METODE}

Penelitian ini merupakan penelitian potong lintang terhadap pasien kanker paru yang dikonsulkan ke bagian Neurologi di RSCM dan RSKD, Jakarta, sepanjang tahun 2018. Kriteria inklusi adalah pasien dewasa yang sudah terdiagnosis sebagai kanker paru berdasarkan pemeriksaan histopatologi dan memiliki data rekam medis lengkap, hingga gambaran CT scan atau MRI kepala dengan kontras. Berdasarkan perhitungan sampel 2 kelompok, dengan asumsi interval kepercayaan $95 \%$, kekuatan $80 \%$, metastasis otak pada KPKSK 40\% dan pada KPKBSK 20\%, maka diperlukan masing-masing 79 sampel untuk masing-masing tipe histopatologi. ${ }^{10,11}$

Variabel yang diinvestigasi dalam penelitian ini adalah data demografi, klinis, dan gambaran imaging. Subjek juga dilakukan penilaian indeks massa tubuh (IMT) dengan kriteria: underweight (IMT $<18,5$ ), normal (IMT 18,5-22,9), dan overweight (IMT $\geq 23$ ). Klasifikasi metastasis SSP dibagi menjadi metastasis otak, metastasis leptomeningeal, metastasis spinal, dan metastasis SSP multipel (gabungan 2 atau lebih metastasis otak, leptomeningeal, atau spinal).

Dalam penelitian ini, juga ingin diketahui perbedaan durasi sakit berdasarkan diagnosis organ tempat tumor pertama kali ditemukan. Oleh karena itu, subjek diklasifikasikan berdasarkan penemuan tumor di paru sebagai organ primer tumor atau di SSP. Jika tumor ditemukan pada paru terlebih dahulu, durasi dinyatakan sebagai selisih waktu antara penemuan tumor di paru dengan penemuan tumor 
di SSP secara radiologis. Jika tumor ditemukan pada SSP terlebih dahulu, durasi dinyatakan sebagai selisih waktu antara penemuan tumor di SSP secara radiologis dengan diagnosis patologi anatomi.

Data diolah secara deskriptif dan analitik menggunakan SPSS ver. 25. Analisis bivariat komparatif menggunakan t-test tidak berpasangan jika sebaran data normal dan Mann-Whitney jika sebaran tidak normal. Uji Chi-square dilakukan pada data kategorik jika nilai expected seluruh sel $>5$, jika tidak memenuhi syarat, dilakukan uji Fisher.

\section{HASIL}

Didapatkan 48 subjek (Tabel 1) dengan median 57 (36-76) tahun, proporsi laki-laki lebih banyak dari pada perempuan $(56,2 \%$ vs $44,8 \%)$ dan $31,3 \%$ mempunyai riwayat merokok. Jenis tumor paru tersering adalah KPKBSK atau NSCLC $(93,75 \%)$.

Tabel 1. Karakteristik Subjek Penelitian $(n=48)$

\begin{tabular}{lc}
\hline Variabel & n (\%) \\
\hline Usia (tahun), Median (Min-maks) & $57(36-76)$ \\
Jenis Kelamin & \\
- Laki-laki & $27(56,2)$ \\
- Perempuan & $21(43,8)$ \\
Pendidikan (n=47) & \\
- $\leq 9$ tahun & $26(55,3)$ \\
- $>9$ tahun & $21(44,7)$ \\
Merokok & \\
- Ya & $15(31,3)$ \\
- Tidak & $33(68,7)$ \\
Jenis Kanker & \\
- KPKBSK & \\
- KPKSK & $45(93,8)$ \\
Indeks Massa Tubuh & $3(6,2)$ \\
- Underweight & \\
- Normal & $9(18,8)$ \\
- Overweight & $25(52,1)$ \\
\hline
\end{tabular}

KPKSK: kanker paru karsinoma sel kecil; KPKBSK: kanker paru karsinoma bukan sel kecil.

Gejala neurologis subjek bervariasi, terutama defisit motorik (62,5\%), nyeri kepala $(43,8 \%)$, gangguan fungsi luhur (20,8\%), dan kejang (18,8\%). Mayoritas subjek mengalami metastasis di otak $(93,8 \%)$ dan sebanyak $8,3 \%$ di leptomeningeal (Tabel 2).

Subjek penelitian ini mempunyai durasi mengalami sakit selama 2-3 bulan (Tabel 3). Kedua
Tabel 2. Gejala Klinis pada Subjek Penelitian $(n=48)$

\begin{tabular}{|c|c|}
\hline Variabel & n (\%) \\
\hline $\begin{array}{l}\text { Nyeri Kepala } \\
\text { - Ya } \\
\text { - Tidak }\end{array}$ & $\begin{array}{l}21(43,8) \\
27(56,3)\end{array}$ \\
\hline $\begin{array}{l}\text { Kejang } \\
\text { - Ya } \\
\text { - Tidak }\end{array}$ & $\begin{array}{c}9(18,8) \\
39(81,2)\end{array}$ \\
\hline $\begin{array}{l}\text { Nyeri Kanker } \\
\text { - Ya } \\
\text { - Tidak }\end{array}$ & $\begin{array}{c}4(8,3) \\
44(91,7)\end{array}$ \\
\hline $\begin{array}{l}\text { Defisit Nervus Kranialis } \\
\text { - Ya } \\
\text { - Tidak }\end{array}$ & $\begin{array}{c}6(12,5) \\
42(87,5)\end{array}$ \\
\hline $\begin{array}{l}\text { Defisit Motorik } \\
\text { - Ya } \\
\text { - Tidak }\end{array}$ & $\begin{array}{l}30(62,5) \\
18(37,5)\end{array}$ \\
\hline $\begin{array}{l}\text { Defisit Sensorik } \\
\text { - Ya } \\
\text { - Tidak }\end{array}$ & $\begin{array}{c}6(12,5) \\
42(87,5)\end{array}$ \\
\hline $\begin{array}{l}\text { Defisit Otonom } \\
\text { - Ya } \\
\text { - Tidak }\end{array}$ & $\begin{array}{c}3(6,3) \\
45(93,8)\end{array}$ \\
\hline $\begin{array}{l}\text { Gangguan Penglihatan } \\
\text { - Ya } \\
\text { - Tidak }\end{array}$ & $\begin{array}{c}0(0) \\
48(100)\end{array}$ \\
\hline $\begin{array}{l}\text { Gambaran Papiledema } \\
\text { - Ya } \\
\text { - Tidak }\end{array}$ & $\begin{array}{c}7(14,6) \\
41(85,4)\end{array}$ \\
\hline $\begin{array}{l}\text { Gangguan Fungsi Luhur } \\
\text { - Ya } \\
\text { - Tidak }\end{array}$ & $\begin{array}{l}10(20,8) \\
38(79,2)\end{array}$ \\
\hline $\begin{array}{l}\text { Lokasi Metastasis } \\
\text { - Otak } \\
\text { - Spinal } \\
\text { - Leptomeningeal }\end{array}$ & $\begin{array}{c}45(93,8) \\
7(14,6) \\
4(8,3)\end{array}$ \\
\hline $\begin{array}{l}\text { Lokasi Metastasis Ekstrakranial } \\
\text { - Hepar } \\
\text { - Tulang }\end{array}$ & $\begin{array}{c}7(14,6) \\
18(37,5)\end{array}$ \\
\hline
\end{tabular}

jenis tumor juga lebih sering menimbulkan gejala di organ primer terlebih dahulu, namun sebanyak $35,4 \%$ jenis KPKBSK bermula gejala di SSP (Tabel 3). Tidak dijumpai hubungan antara faktor-faktor gejala klinis dengan jenis tumor paru (Tabel 4).

Pada Tabel 5 dijumpai terdapat kecenderungan metastasis SSP multipel pada pasien KPKBSK $(\mathrm{p}=0,015)$. Subjek dengan KPKSK memiliki kecenderungan metastasis lebih besar disbanding subjek KPKBSK (33,3\% vs 8,9\%) Selain itu, pasien 
Tabel 3. Perbandingan Presentasi Lokasi Gejala Klinis Awal Subjek $(\mathrm{n}=48)$

\begin{tabular}{|c|c|c|c|}
\hline \multirow[b]{2}{*}{ Variabel } & \multicolumn{2}{|c|}{$\begin{array}{c}\text { Lokasi Gejala Klinis } \\
\text { Awal }\end{array}$} & \multirow[b]{2}{*}{ p } \\
\hline & $\begin{array}{l}\text { Organ } \\
\text { Primer } \\
(n=31)\end{array}$ & $\begin{array}{c}\text { SSP } \\
(n=17)\end{array}$ & \\
\hline $\begin{array}{l}\text { Durasi sakit (bulan), } \\
\text { Median (Min-maks) }\end{array}$ & $3(0,75-36)$ & $2(0,25-9)$ & $0,149 *$ \\
\hline $\begin{array}{l}\text { Jenis Tumor } \\
\text { - KPKBSK } \\
\text { - KPKSK }\end{array}$ & $\begin{array}{c}28(58,3) \\
3(6,3)\end{array}$ & $\begin{array}{c}17(35,4) \\
0\end{array}$ & $0,543^{\#}$ \\
\hline
\end{tabular}

*Uji Mann-Whitney; "Uji Fisher; SSP: susunan saraf pusat; KPKSK: kanker paru karsinoma sel kecil; KPKBSK: kanker paru karsinoma bukan sel kecil.

Tabel 4. Hubungan antara Jenis Tumor Paru dengan Klinis $(n=48)$

\begin{tabular}{|c|c|c|c|}
\hline \multirow{2}{*}{ Variabel } & \multicolumn{2}{|c|}{ Jenis Tumor Paru } & \multirow{2}{*}{$\mathbf{p}^{*}$} \\
\hline & KPKBSK & KPKSK & \\
\hline $\begin{array}{l}\text { Sefalgia } \\
\text { - Ya } \\
\text { - Tidak }\end{array}$ & $\begin{array}{l}20 \\
25\end{array}$ & $\begin{array}{l}1 \\
2\end{array}$ & 1,000 \\
\hline $\begin{array}{l}\text { Kejang } \\
\text { - Ya } \\
\text { - Tidak }\end{array}$ & $\begin{array}{c}8 \\
37\end{array}$ & $\begin{array}{l}1 \\
2\end{array}$ & 0,472 \\
\hline $\begin{array}{l}\text { Nyeri Kanker } \\
\text { - Ya } \\
\text { - Tidak }\end{array}$ & $\begin{array}{c}3 \\
42\end{array}$ & $\begin{array}{l}1 \\
2\end{array}$ & 0,234 \\
\hline $\begin{array}{l}\text { Defisit N. Kranialis } \\
\text { - Ya } \\
\text { - Tidak }\end{array}$ & $\begin{array}{c}5 \\
40\end{array}$ & $\begin{array}{l}1 \\
2\end{array}$ & 0,336 \\
\hline $\begin{array}{l}\text { Defisit Motorik } \\
\text { - Ya } \\
\text { - Tidak }\end{array}$ & $\begin{array}{l}27 \\
18\end{array}$ & $\begin{array}{l}3 \\
0\end{array}$ & 0,282 \\
\hline $\begin{array}{l}\text { Defisit Sensorik } \\
\text { - Ya } \\
\text { - Tidak }\end{array}$ & $\begin{array}{c}5 \\
40\end{array}$ & $\begin{array}{l}1 \\
2\end{array}$ & 0,336 \\
\hline $\begin{array}{l}\text { Defisit Otonom } \\
\text { - Ya } \\
\text { - Tidak }\end{array}$ & $\begin{array}{c}3 \\
42\end{array}$ & $\begin{array}{l}0 \\
3\end{array}$ & 1,000 \\
\hline $\begin{array}{l}\text { Defisit Kognitif } \\
\text { - Terganggu } \\
\text { - Normal }\end{array}$ & $\begin{array}{l}10 \\
35\end{array}$ & $\begin{array}{l}0 \\
3\end{array}$ & 1,000 \\
\hline $\begin{array}{l}\text { Papilledema } \\
\text { - Ya } \\
\text { - Tidak }\end{array}$ & $\begin{array}{c}7 \\
38\end{array}$ & $\begin{array}{l}0 \\
3\end{array}$ & 1,000 \\
\hline
\end{tabular}

*Uji Fisher; KPKSK: kanker paru karsinoma sel kecil; KPKBSK: kanker paru; karsinoma bukan sel kecil.

merokok juga memiliki kecenderungan metastasis SSP multipel dibandingkan yang tidak merokok
$(33,3 \%$ vs $3 \%)$. Terdapat perbedaan bermakna tempat metastasis dengan status merokok $(\mathrm{p}=0,010)$.

\section{PEMBAHASAN}

Dalam penelitian ini, didapati median umur kanker paru adalah 57 tahun, sesuai dengan Harsal dkk di RSKD bahwa rerata usia pasien kanker paru 57 tahun. ${ }^{12}$ Namun usia ini jauh lebih muda dibandingkan Torre dkk yang menyatakan median umur kanker paru baru terdiagnosis adalah 70 tahun. ${ }^{13}$ Belum diketahui penyebab lebih mudanya rerata umur pasien dengan kanker paru di Indonesia. Oleh karena itu, hal ini menarik untuk dievaluasi lebih lanjut.

Sebagian besar penderita kanker paru adalah laki-laki, merupakan kanker tersering pada laki-laki (14\%) di Indonesia. Populasi global menunjukkan kanker paru pada laki-laki 19,4\% dan perempuan $6 \%$ dengan rasio $3: 1.5$ Namun proporsi laki-laki dan perempuan dalam penelitian ini hampir sama, yaitu $56,3 \%$ dan $43,8 \%$. Perbandingan ini mirip dengan penelitian Waqar dkk, yaitu 59,8\% subjek dengan metastasis otak adalah laki-laki. ${ }^{14}$ Adapun An dkk menyatakan metastasis otak pada kanker paru lebih sering ditemukan pada perempuan dibandingkan laki-laki. ${ }^{15}$

Banyaknya proporsi subjek perempuan dalam penelitian ini kemungkinan akibat meningkatnya prevalensi kanker paru pada perempuan. Hal ini diungkapkan oleh Sutandyo dkk yang meneliti kanker paru pada perempuan, bahwa peningkatan kanker paru pada perempuan dapat disebabkan oleh sebagai perokok pasif, paparan lingkungan, presdisposisi genetik, dan infeksi virus. ${ }^{16}$ Namun, belum dikaji lebih mendalam faktor apa saja yang menyebabkan banyaknya proporsi subjek penelitian dalam penelitian ini.

Indeks massa tubuh pada subjek dalam penelitian ini sebagian besar $(52,1 \%)$ memiliki IMT normal dan 29,2\% memiliki berat badan (BB) berlebih. Relasi antara IMT dengan metastasis otak pernah diteliti sebelumnya oleh Nam dkk, bahwa BB kurang berkorelasi dengan kejadian metastasis otak pada KPKBSK, namun obesitas dapat menjadi faktor protektif yang melindungi dari metastasis 
Tabel 5. Hubungan antara Metastasis SSP dengan Jenis Kanker Paru, Jenis Kelamin, Usia, dan Merokok (n=48)

\begin{tabular}{|c|c|c|c|c|}
\hline Variabel & $\begin{array}{c}\text { Otak } \\
\text { n (\%) }\end{array}$ & $\begin{array}{c}\text { Spinal } \\
\text { n }(\%)\end{array}$ & $\begin{array}{c}\text { Multipel } \\
\text { n (\%) }\end{array}$ & $\mathbf{p}^{*}$ \\
\hline $\begin{array}{l}\text { Jenis Tumor } \\
\text { - KPKBSK } \\
\text { - KPKSK }\end{array}$ & $\begin{array}{c}38(84,4) \\
1(33,3)\end{array}$ & $\begin{array}{c}3(6,7) \\
0(0)\end{array}$ & $\begin{array}{c}4(8,9) \\
2(66,7)\end{array}$ & 0,015 \\
\hline $\begin{array}{l}\text { Jenis Kelamin } \\
\text { - Laki-laki } \\
\text { - Perempuan }\end{array}$ & $\begin{array}{l}20(74,1) \\
19(90,5)\end{array}$ & $\begin{array}{l}2(7,4) \\
1(4,7)\end{array}$ & $\begin{array}{c}2(7,4) \\
0(0)\end{array}$ & 0,322 \\
\hline Usia (tahun), Rerata \pm SD & $55,9 \pm 8,3$ & $49,7 \pm 15,8$ & $67,5 \pm 12$ & 0,407 \\
\hline $\begin{array}{l}\text { Merokok } \\
\text { - Ya } \\
\text { - Tidak }\end{array}$ & $\begin{array}{l}10(66,7) \\
29(87,9)\end{array}$ & $\begin{array}{c}0(0) \\
3(9,1)\end{array}$ & $\begin{array}{c}5(33,3) \\
1(3)\end{array}$ & 0,010 \\
\hline
\end{tabular}

*Uji Kruskal-Wallis; KPKSK: kanker paru karsinoma sel kecil; KPKBSK: kanker paru karsinoma bukan sel kecil; SD: standar deviasi.

otak. ${ }^{17}$ Penelitian ini mendapatkan $31,3 \%$ subjek yang merokok yang keseluruhannya adalah lakilaki. Dalam penelitian yang dilakukan Zeng dkk mengenai perokok pada subjek perempuan, ditemukan hanya $10,7 \%$ subjek yang merokok. ${ }^{18}$ Hal ini memperlihatkan bahwa terdapat faktor lain selain merokok yang menjadi faktor risiko kanker paru pada perempuan. Merokok diketahui sebagai faktor risiko terjadinya kanker paru serta faktor risiko kematian akibat metastasis otak. ${ }^{19}$ Subjek yang merokok penelitian ini ditemui relatif sedikit, namun second-hand smoking dan faktor-faktor lainnya tidak diinvestigasi lebih.

Metastasis terbanyak $(93,8 \%)$ penelitian ini adalah ke otak dan sebanyak $8,3 \%$ subjek mengalami metastasis leptomeningeal. Hasil penelitian ini mirip dengan literatur sebelumnya yang menyebutkan dari seluruh metastasis SSP, metastasis leptomeningeal ditemukan pada $9 \%$ pasien ${ }^{9}$ dan Chi dkk bahwa angka metastasis leptomeningeal pada pasien kanker paru dapat mencapai $10 \%$ pada studi otopsi. ${ }^{8}$

Dalam penelitian ini, didapati defisit motorik $(62,5 \%)$, nyeri kepala $(43,8 \%)$, gangguan fungsi luhur (20,8\%), dan kejang (18,8\%). Nyeri kepala tersebut mirip dengan penelitian Lee dkk pada pasien dengan metastasis otak sebanyak 50\%. Menurut Steindl $\mathrm{dkk}$, defisit neurologis metastasis otak pada kanker paru mencapai $60,7 \%$ saat diagnosis mirip dengan penelitian ini dimana defisit neurologis motorik mencapai $62,5 \%{ }^{20}$ Hasil ini sejalan dengan Soffietti dkk bahwa pada metastasis otak didapatkan nyeri kepala (40-50\%), kejang (15-20\%), dan defisit neurologis lainnya hingga $40 \%$ pasien. $^{2}$ Dalam penelitian ini, sulit diambil kesimpulan yang representatif karena tidak terpenuhinya jumlah subjek minimal KPKSK dan KPKBSK. Selain itu, gejala neurologis sangat dipengaruhi lokasi dan volume tumor. Hingga saat ini, belum ada penelitian yang membandingkan mengenai perbedaan manifestasi neurologis pada subtipe kanker paru KPKSK dan KPKBSK yang bermetastasis ke otak. Namun, dalam penelitian ini didapati tidak ada perbedaan bermakna gejala neurologis yang dialami pasien KPKSK dan KPKBSK.

Waktu antara timbulnya gejala awal tumor primer paru sampai diagnosis tumor metastasis SSP berkisar $3(0,75-36)$ bulan. Waktu antara kecurigaan tumor metastasis SSP sampai didapat hasil patologi anatomi kanker paru berkisar antara 0,25-9 bulan, dengan waktu median 2 bulan. Tidak ada perbedaan bermakna antara kedua grup $(\mathrm{p}=0,149)$. Hal ini menunjukkan bahwa massa tumor intrakranial metastasis memiliki progresi yang cukup cepat dari yang awalnya sudah diketahui tumor primernya ataupun belum. Sebanyak 37,8\% subjek KPKBSK diketahui sebagai tumor intrakranial pada awal diagnosisnya, sementara seluruh subjek KPKSK pada awalnya diketahui sebagai tumor primer. Meskipun pada literatur sebelumnya diketahui bahwa risiko KPKSK untuk metastasis intrakranial lebih tinggi dibandingkan KPKBSK, ${ }^{8}$ sebaliknya pada penelitian ini. Hal ini dimungkinkan akibat sedikitnya subjek dengan KPKSK, sehingga tidak representatif terhadap hasil penelitian. 
Terdapat proporsi metastasis SSP multipel lebih banyak pada subjek KPKSK dan subjek perokok dalam penelitian ini $(\mathrm{p}=0,015 ; \mathrm{p}=0,010)$. Hasil analisis post-hoc menunjukkan tumor jenis KPKSK memiliki kecenderungan metastasis SSP lebih tinggi dibandingkan dengan KPKBSK (p $=0,005)$. Selain itu, terdapat hubungan antara merokok dengan metastasis multipel secara posthoc $(\mathrm{p}=0,006)$. Merokok merupakan faktor risiko untuk terjadinya metastasis SSP dan memperburuk prognosis kesintasan. ${ }^{19}$

Namun, belum ada penelitian yang menjelaskan hubungan antara merokok dengan metastasis SSP multipel pada kanker paru. Yan dkk juga menyatakan bahwa pada pasien KPKBSK dengan metastasis leptomeningeal dan metastasis otak secara bersamaan ditemukan pada 39,7\% pasien. Angka ini cukup besar dibandingkan dalam penelitian ini, yaitu hanya $8,9 \%$. Hal ini mungkin dapat dijelaskan dengan keterbatasan penggunaan fasilitas penunjang pencitraan MRI/ CT scan serial yang dapat menyebabkan banyak tidak terdiagnosisnya metastasis leptomeningeal bersamaan dengan metastasis otak dengan baik. ${ }^{21}$

Penelitian ini merupakan penelitian pertama di Indonesia yang meneliti metastasis SSP pada kanker paru. Terdapat beberapa keterbatasan dalam penelitian ini. Penelitian ini merupakan penelitian potong lintang dimana pasien tidak diikuti perkembangan klinis dari awal hingga akhir. Selain itu, pasien yang dijadikan subjek adalah pasien yang dirawat oleh departemen neurologi saja sehingga belum merepresentasikan populasi secara umum. Analisis volume dan lokasi metastasis dan edema peritumoral yang sering terjadi pada tumor belum dilakukan dalam penelitian ini berpotensi memengaruhi gejala klinis yang dialami pasien. Penelitian lanjutan dengan sampel yang lebih banyak serta bersifat prospektif dan melibatkan parameter-parameter lainnya dapat dilakukan untuk menilai metastasis SSP pada kanker paru secara lebih komprehensif.

\section{KESIMPULAN}

Dalam penelitian ini, didapati komplikasi neurologis pada kanker paru yang cukup tinggi. Namun, penelitian ini tidak dapat membuktikan adanya hubungan jenis tumor paru dengan gejala neurologis yang dialami pasien ataupun durasi metastasis otak. Terdapat kecenderungan metastasis SSP multipel pada KPKSK dan pasien yang merokok. Namun, jumlah sampel dalam penelitian ini belum cukup representatif untuk mengambil kesimpulan sehingga diperlukan penelitian dengan subjek yang lebih banyak.

\section{DAFTAR PUSTAKA}

1. Andriani R, Citra I. Tumor Otak Sekunder(Metastasis). In: Aninditha T, Andriani R, Malueka RG, editors. Buku Ajar Neuroonkologi. Jakarta: Penerbit Kedokteran Indonesia; 2019.

2. Soffietti R, Franchino F, Ruda R. Brain metastasis as complication of systemic cancers. In: Schiff D, Arrilaga I, Wen PY, editors. Cancer Neurology in Clinical Practice. 3rd ed. Boston: Springer; 2018.

3. Loeffler JS. Epidemiology, clinical manifestations, and diagnosis of brain metastases2019 Nov 2019. Available from: uptodate.com.

4. Jack MM, Gattozzi DA, Arnold PM. Multiple intraparenchymal cystic brain metastases - a rare manifestation of metastatic adenocarcinoma of the prostate. Interdisc Neurosurg. 2018;14:53-5.

5. GLOBOCAN. Indonesia [Internet]. IARC. 2018.

6. Jusuf A, Syahrudin E, Wibawanta A, Ichsan AG, Juniarti, Endardjo S, et al. Kanker Paru (Kanker Paru Jenis Karsinoma Bukan Sel Kecil) Pedoman Diagnosis dan Penatalaksanaan di Indonesia. Jakarta: PDPI; 2011.

7. Bray F, Ferlay J, Soerjomataram I, Siegel RL, Torre LA, Jemal A. Global cancer statistics 2018: GLOBOCAN estimates of incidence and mortality worldwide for 36 cancers in 185 countries. CA Cancer J Clin. 2018;68(6):394-424.

8. Chi M, Ahluwalia MS. Neurological Complication of Lung Cancer. In: Schiff D, Arrilaga I, Wen PY, editors. Cancer Neurology in Clinical Practice. Boston: Springer; 2018.

9. Hendriks LEL, Subramaniam DS, Dingemans AC. Editorial: Central Nervous System Metastases in Lung Cancer Patients: From Prevention to Diagnosis and Treatment. Front Oncol. 2018;8:511.

10. Ali A, Goffin JR, Arnold A, Ellis PM. Survival of patients with non-small-cell lung cancer after a diagnosis of brain metastases. Curr Oncol. 2013;20(4):e300-6.

11. Kepka L. Radiotherapy of brain metastases from small-cell lung cancer: standards and controversies. J Cancer Metastasis Treat. 2019;5(53).

12. Harsal A, Suratman E, Tambunan T. Overview of 
lung cancer in Dharmais National Cancer Hospital, Jakarta, Indonesia. J Thorac Oncol. 2007;2(8).

13. Torre LA, Siegel RL, Jemal A. Lung Cancer Statistics. Adv Exp Med Biol. 2016;893:1-19.

14. Waqar SN, Waqar SH, Trinkaus K, Gadea CA, Robinson CG, Bradley J, et al. Brain Metastases at Presentation in Patients With Non-Small Cell Lung Cancer. Am J Clin Oncol. 2018;41(1):36-40.

15. An N, Jing W, Wang H, Li J, Liu Y, Yu J, et al. Risk factors for brain metastases in patients with non-smallcell lung cancer. Cancer Med. 2018;7(12):6357-64.

16. Sutandyo N, Suratman E. Non-small cell lung carcinoma in women: retrospective cohort study in Indonesia. Indones J Intern Med. 2018;50(4):291-8.

17. Nam MW, Kim JM, Cheong JH, Ryu JI, Han MH. Paradoxical relationship between body mass index and bone mineral density in patients with non-small cell lung cancer with brain metastasis. PLoS One. 2019;14(6):e0218825.

18. Zeng Q, Vogtmann E, Jia MM, Parascandola M, $\mathrm{Li} \mathrm{JB}, \mathrm{Wu}$ YL, et al. Tobacco smoking and trends in histological subtypes of female lung cancer at the Cancer Hospital of the Chinese Academy of Medical Sciences over 13 years. Thorac Cancer. 2019;10(8):1717-24.

19. Shenker RF, McTyre ER, Ruiz J, Weaver KE, Cramer C, Alphonse-Sullivan NK, et al. The Effects of smoking status and smoking history on patients with brain metastases from lung cancer. Cancer Med. 2017;6(5):944-52.

20. Steindl A, Schlieter F, Klikovits T, Leber E, Gatterbauer B, Frischer JM, et al. Prognostic assessment in patients with newly diagnosed small cell lung cancer brain metastases: results from a reallife cohort. J Neurooncol. 2019;145(1):85-95.

21. Yan W, Jing W, An N, Tian Y, Guo D, Kong L, et al. The clinical characteristic and prognostic factors of leptomeningeal metastasis in patients with nonsmall-cell lung cancer-a retrospective study from one single cancer institute. Cancer Med. 2019;8(6):276976. 